\title{
A Survey of Students' Motivation in College English Learning Under Production-Oriented Approach in NCEPU
}

\author{
Junhong Ren ${ }^{1} \& \mathrm{Na}$ Wang ${ }^{1}$ \\ ${ }^{1}$ School of Foreign Languages, North China Electric Power University, Baoding, China \\ Correspondence: Junhong Ren, School of Foreign Languages, North China Electric Power University, Baoding, \\ Hebei Province, China.
}

Received: October 5, 2018 Accepted: November 19, 2018 Online Published: November 22, 2018

doi: 10.5539/elt.v11n12p199 URL: https://doi.org/10.5539/elt.v11n12p199

\begin{abstract}
This study investigates students' motivation in college English learning under production-oriented approach by means of a questionnaire. Forty students in their first-year study participated in this survey. They came from four different disciplines: electronic engineering, automatic engineering, mechanic engineering and power engineering. They were required to fill in the questionnaire at the beginning of the second semester before the teaching reform and at the end of the second semester when the teaching reform was conducted respectively. Our study indicates that students in increasing numbers begin to show great interest in college English learning under POA, and their intrinsic motivation in English learning has been strengthened while at the same time extrinsic motivation shows a tendency of decline. The potential implication of this finding is that POA may be effective in stimulating students' motivation in college English learning.
\end{abstract}

Keywords: motivation, college English learning, POA, NCEPU

\section{Introduction}

Level-based college English teaching has seemingly lost its appeal to students in North China Electric Power University (NCEPU). Our previous study has indicated that students from different achievement groups tend to hold neutral attitude toward this teaching practice, including teaching approach, teaching materials and teaching methods. Furthermore, alterations are in desperate need if it were to regain students' interest. (Ren, 2016; Ren \& Wang, 2018a).

One possible reason for its failure to stimulate students' interest in English learning may lie in the fact that this kind of classification has to a great extent done harm to the self-esteem of students from mid-level achievement groups. Another possible reason, and the one that needs our special attention, would be the disjunction of learning and using. It is undoubtedly the case that English language teaching has been conducted in China for several decades, and that most students have learned English since primary school, however, the English levels of most students have not yet developed to such an extent that they could read or write or speak fluently and smoothly as is expected. The underlying reason may be that we have placed too much emphasis on language input, without laying equal stress on language output.

To overcome this weakness in college English teaching, Wen $(2015,2016,2017)$ developed the production-oriented approach (POA). POA is composed of three components: teaching principles, teaching hypothesis and teacher-mediated teaching process. POA advocates learning-centered, learning-using integrated and whole-person education principles, emphasizing the leading role of a teacher in classroom instruction and aiming to conduct English lessons under the output-driven, input-enabled and selective learning hypotheses.

Recently, POA-related experimental studies have been conducted ranging from English language instruction to textbook writing in Mainland China. (Zhang, W. J. 2015, 2016, 2017; Zhang, L. L. 2017; Chang, 2017). These studies have indicated that POA is conducive to college English teaching. Zhang (2017) conducted an experimental study on the effectiveness of the production-oriented approach (POA) in college English teaching. Her study revealed that experimental group (EG) showed significant increase in listening and writing skills, significant decrease in reading skill, and no significant change in translation skill in comparison with that of the control group (CG). Furthermore, the high proficiency students in EG improve significantly, as compared to those in CG. Thirdly, EG hold positive attitudes towards POA, which stimulates greatly their motivation in 
English learning.

Zhang (2015) reported a two-week EFL classroom teaching practice for university students under the Production-Oriented Approach (POA). The teaching practice included the teaching objectives, the teaching design and the procedure of classroom teaching especially the "enabling" stage. The approach yields some preliminary efficacy when students are enabled to produce through selective learning with the teacher's mediation.

Zhang (2016) reported a three-week classroom experiment on Production-oriented Approach (POA). The main tools in this experiment were questionnaires and interviews, the author's reflection based on her classroom observation and reflective journals. This report indicated that both students and co-workers had positive feedback toward this new teaching approach.

Zhang (2017) conducted an experimental study on the effect of the production-oriented approach on college students' English writing quality. Results of the pre-test and posttest writing samples of both experiment and control groups revealed that while no significant differences are found in the global, the experiment group outscore the control group in respects of content, structure and language; and that the experiment group's writing production contain more newly-taught target linguistic items than that of the control group.

Chang (2017) made explorations of textbook writing based on POA. A "Teaching theory-Action research" Integrated Model was introduced in this study. In this model, teaching theories and action research were integrated in a complementary and interactive way at different stages of textbook writing. Relevant research indicated that this model can facilitate both theory refinement and textbook improvement, thus conducive to the practice and research of ELT textbook writing.

These studies seemingly offer empirical evidence for us to conduct teaching reforms in college English teaching in respect of teaching materials and teaching practice. One can easily draw the conclusion from the studies that POA is effective to college English learning and students are more likely to be motivated by this new teaching approach to put what is learned into practical use in English writing. One thing that needs to take into account, however, is that most of the experiments last for at most three weeks; whether the result would be different were the experiments last for a relatively long period of time is still unknown.

Taking into consideration the current situation of college English teaching in NCEPU, we initiated a teaching reform under POA in an effort to renew students' interest in English learning and encourage them to put what is learned into practical use (Ren, 2017; Ren \& Wang, 2018b). We took reforms in teaching materials, teaching process and assessment (Ren \& Wang, 2018b, 2018c, 2018d). Our teaching experiment lasted for a semester. In order to assess the effect of this teaching approach on students' motivation, we initiated a survey on students' perception of POA on their motivation in college English learning in NCEPU.

\section{A survey of the Effect of POA on Students' Motivation in College English Learning in NCEPU}

\subsection{Research Questions}

POA has been proved by some scholars to be effective in improving students' motivation in English study in some universities in mainland China. It is our expectation that it would yield similar results in NCEPU. For this purpose and the purpose aforementioned, this survey aim to answer the question of to what extent POA could stimulate students' motivation in college English learning.

\subsection{Participants}

The participants were students recruited from NCEPU. A total of 40 students from two classes who were in their first year of study, took part in the survey that was conducted at the beginning of the second semester and at the end of the semester respectively. They brought a rich variety of background to the survey and represented four different discipline areas of electric engineering, automatic engineering, mechanical Engineering and power engineering.

\subsection{Instrument}

In this survey, the questionnaire was the main tool of investigation. It had been revised according to a survey from a professional online questionnaire platform. This questionnaire was composed of two sections. Section one requested biographic information of the participants, including their gender, major, class and grade. In section two, twelve items on students' motivation of English learning were put forth. The participants were requested to choose the alternatives suitable for their own condition.

\subsection{Process}


This questionnaire was handed out to the students both at the beginning and at the end of the second semester. The students were required to finish the questionnaire in normal class time. Investigators were there to provide help when necessary. In order to reduce possible power dynamics, the researcher assured the students that the choices had nothing to do with their grade. The students finished answering the questionnaire independently. It took about 15 minutes.

\subsection{Data Analysis}

The quantitative data collected from the questionnaire were entered into Excel and the results were presented in the form of percentage. Also employed were some figures in bar charts.

\section{Results and Discussion}

The following table presents the result from the survey.

Table 1. Changes of students' motivation in college English learning

\begin{tabular}{lllllllllll}
\hline Items & \multicolumn{3}{c}{ Pre-test } & \multicolumn{5}{c}{ Post-test } \\
\cline { 2 - 11 } & $\mathrm{A}$ & $\mathrm{B}$ & $\mathrm{C}$ & $\mathrm{D}$ & $\mathrm{E}$ & $\mathrm{A}$ & $\mathrm{B}$ & $\mathrm{C}$ & $\mathrm{D}$ & $\mathrm{E}$ \\
\hline 1 & $2.5 \%$ & $20 \%$ & $27.5 \%$ & $27.5 \%$ & $17.5 \%$ & $15 \%$ & $30 \%$ & $40 \%$ & $15 \%$ & $0 \%$ \\
2 & $7.5 \%$ & $5 \%$ & $32.5 \%$ & $27.5 \%$ & $27.5 \%$ & $0 \%$ & $5 \%$ & $35 \%$ & $45 \%$ & $15 \%$ \\
3 & $5 \%$ & $7.5 \%$ & $37.5 \%$ & $30 \%$ & $20 \%$ & $0 \%$ & $5 \%$ & $35 \%$ & $45 \%$ & $15 \%$ \\
4 & $7.5 \%$ & $10 \%$ & $30 \%$ & $25 \%$ & $27.5 \%$ & $0 \%$ & $15 \%$ & $40 \%$ & $25 \%$ & $20 \%$ \\
5 & $5 \%$ & $5 \%$ & $32.5 \%$ & $37.5 \%$ & $20 \%$ & $0 \%$ & $5 \%$ & $15 \%$ & $40 \%$ & $40 \%$ \\
6 & $7.5 \%$ & $22.5 \%$ & $42.5 \%$ & $12.5 \%$ & $12.5 \%$ & $5 \%$ & $30 \%$ & $35 \%$ & $20 \%$ & $10 \%$ \\
7 & $5 \%$ & $17.5 \%$ & $32.5 \%$ & $22.5 \%$ & $22.5 \%$ & $0 \%$ & $15 \%$ & $25 \%$ & $40 \%$ & $20 \%$ \\
8 & $5 \%$ & $12.5 \%$ & $45 \%$ & $22.5 \%$ & $15 \%$ & $0 \%$ & $5 \%$ & $30 \%$ & $35 \%$ & $30 \%$ \\
9 & $7.5 \%$ & $12.5 \%$ & $35 \%$ & $32.5 \%$ & $12.5 \%$ & $5 \%$ & $0 \%$ & $25 \%$ & $50 \%$ & $20 \%$ \\
10 & $5 \%$ & $25 \%$ & $32.5 \%$ & $25 \%$ & $12.5 \%$ & $5 \%$ & $5 \%$ & $25 \%$ & $30 \%$ & $35 \%$ \\
11 & $7.5 \%$ & $2.5 \%$ & $30 \%$ & $42.5 \%$ & $17.5 \%$ & $5 \%$ & $10 \%$ & $30 \%$ & $25 \%$ & $30 \%$ \\
12 & $5 \%$ & $5 \%$ & $35 \%$ & $32.5 \%$ & $22.5 \%$ & $0 \%$ & $5 \%$ & $30 \%$ & $25 \%$ & $40 \%$ \\
\hline
\end{tabular}

Motivation has been regarded as one of the most important factors that inspire a person to move forward. It can be divided into intrinsic (internal or inherent) motivation and extrinsic (external) motivation. Intrinsic motivation refers to the self-desire to seek out new things and new challenges, to analyze one's capacity, to observe and to gain knowledge. Extrinsic motivation comes from influences outside of the individual. (Ryan and Deci, 2000) Based on this classification, the twelve items were grouped into two dimensions, namely, items aimed to investigate students' intrinsic motivation in college English learning and those designed to survey students' extrinsic motivation in college English learning. 


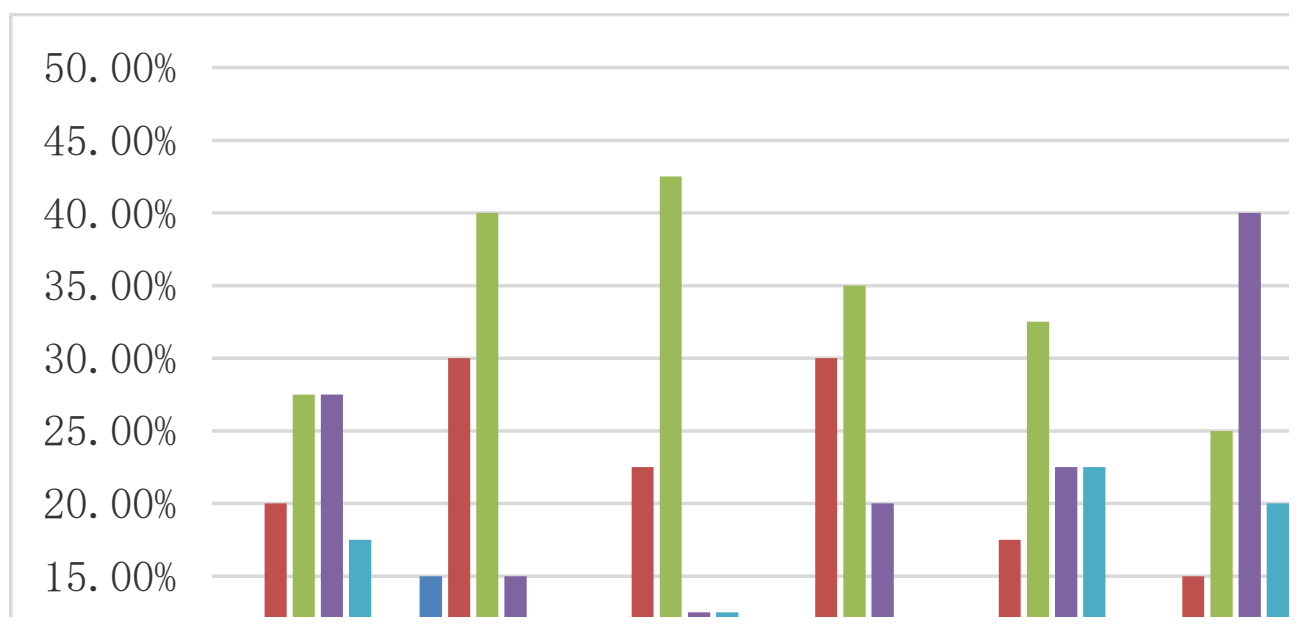

Figure 1. Changes of intrinsic motivation in college English learning

Figure 1 shows changes of students' intrinsic motivation in English learning. It can be seen that students' intrinsic motivation in English learning in general changed, although not yet changed substantially, in our teaching experiment. Answers to question 1 in the pretest and post-test indicated that more students were motivated to learn English because of their desire to know English-speaking people and communicate with them. Furthermore, the number of students who became interested in language learning increased to some extent, which could be shown from the changes between pre- 6 and post- 6 . One interesting phenomenon that requires our attention is that although some of them claimed interest in English learning, they did not seem to hold the same interest in foreign literature, songs, movies or culture, nor were they willing to devote more time and energy into English study even if they had made clear English learning goals. One possible explanation could be that our new teaching reform has aroused students' interest in English learning, yet more efforts are needed to strengthen this interest so that students could internalize this interest and transform it into motivation.

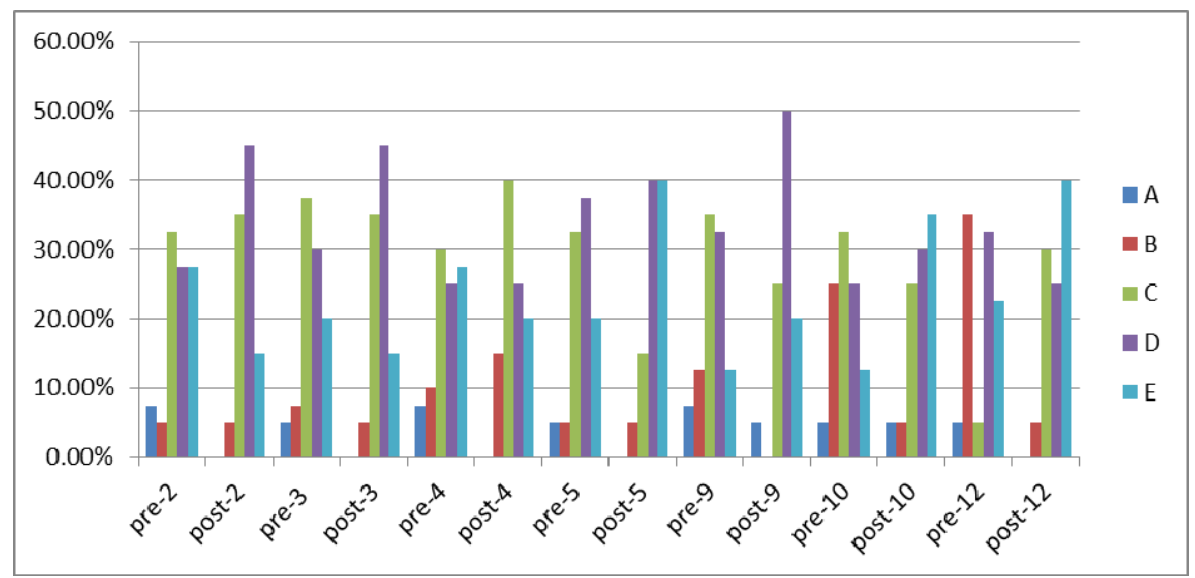

Figure 2. Changes of extrinsic motivation in college English learning

Figure 2 indicates the changes of students' extrinsic motivation in college English learning. It can be seen from the figure that students' extrinsic motivation in college English learning in general declined. Answers to questions 2, 4 and 12 in the pretest and posttest showed that students in increasing numbers did not learn English because of the influences from their friends or classmates, nor because of the high marks and material rewards, nor because of the praise they got from English teachers for their good performance and progress. Answers to question 3 and 5 indicated that an increasing number of students did not learn English in order to pass sorts of English tests, they no longer saw English as a tool for future jobs. Answers to question 9 and 10 suggested that English teachers and parents were not factors that could affect their English study for a growing number of students. The possible explanation could be that students had come to appreciate English learning under our new teaching reform. 
Our findings indicate that students in general hold positive feedback toward this new teaching approach. This is consistent with what Zhang, W. J. (2016, 2017) and Zhang, L. L. (2017) has suggested. Furthermore, our survey shows that students in increasing numbers are motivated to learn English out of interest in English study instead of influences from outside of the individual. This finding is of great significance, because it implies that POA is very effective in college English instruction, and that our teaching aims, teaching designs and teaching process, especially the output-driven, input-enabled phase have been acknowledged by a growing number of students.

\section{Conclusion}

My aim in this study was to investigate, by means of a questionnaire, students' motivation in English learning under POA. The items in the questionnaire were divided into two dimensions, namely the intrinsic motivation and extrinsic motivation. From their responses to statements about motivation in English learning, it appears that most of the first-year students take positive attitude toward this new teaching approach. They tend to be more motivated in English learning under POA, although their motivation needs to be further strengthened.

However, because this study was small in scale, it would be imprudent to generalize its findings too broadly. But the study does suggest two implications for college English teaching. To begin with, the results of the study suggest that while not all of the students have been motivated in English study, students in growing numbers do come to construe their English learning in a way different from before. This can be shown from the declined extrinsic motivation and fortifying intrinsic motivation in their English study. This fact leads us to the second implication, that is, POA may be effective in stimulating students' motivation in college English learning. The teaching principles and teaching process under POA may be viable in our college English classroom instruction.

\section{Acknowledgement}

This work is sponsored by “the Fundamental Research Funds for the Central Universities" (Grant \#2015MS70)

\section{References}

Chang, X. L. (2017).Textbook writing based on the production-oriented approach. Modern Foreign Languages, 40(3), 359-368.

Ren, J. H. (2016). College English classroom instructions in China: Crisis and solutions. In H. Zhang (Ed.), Proceedings of $20163^{\text {rd }}$ International Conference on Economic, Business Management and Education Innovation, 55, 422-424.

Ren, J. H., \& Wang, N. (2018a). A survey of students' attitude toward English graded teaching in China: A case study of North China Electric Power University. English Language Teaching, 11(5), 24-32.

Ren, J. H., \& Wang, N. (2018b). Production-Oriented Approach and its implications for the cultivation of critical thinking skills in college English instruction in Mainland China. English Language Teaching, 11(5), 33-38. https://doi.org/10.5539/elt.v11n5p33

Ren, J. H., \& Wang, N. (2018c). The new college English teaching reform in NCEPU: A teaching experiment. Journal of English Language and Literature, 10(2), 1001-1004. https://doi.org/10.17722/jell.v10i2.397

Ren, J. H., \& Wang, N. (2018d). College English Reading Instruction in North China Electric Power University: The Production-Driven Approach. English Language Teaching, 11(10), 10-15. https://doi.org/10.5539/elt.v $11 \mathrm{n} 10 \mathrm{p} 10$

Ryan, R. M., \& Deci, E. L. (2000). Self-determination theory and the facilitation of intrinsic motivation, social development, and well-being. American Psychologist, 55(1), 68-78. https://doi.org/10.1037/0003-066X.55. 1.68

Wen, Q. F. (2015). Developing a theoretical system of production-oriented approach in language teaching. Foreign Language Teaching and Research, 4, 547-558.

Wen, Q. F. (2016). Teacher-Student Collaborative Assessment: An innovative assessment method for the Production-oriented Approach. Foreign Language World, 5, 37-43.

Wen, Q. F. (2017). Chinese features displayed in the production-oriented approach. Modern Foreign Languages, $3,348-359$.

Zhang, W. J. (2015). "Enabling" students' production to enable students' language development: Applying production-oriented approach to TEFL classroom. Foreign Lanuage Education in China, 8(11), 10-17.

Zhang, W. J. (2016). Applying Production-oriented Approach to college English classrooms: A teaching experiment. Foreign Languages and Their Teaching, 2, 106-114. 
Zhang, L. L. (2017). An experimental study on the effectiveness of the production-oriented approach. Modern Foreign Languages, 40(3), 369-376.

Zhang W. J. (2017). An experimental study on the effect of the production-oriented approach on college students' English writing quality. Modern Foreign Languages, 40(3), 377-385.

\section{Appendix}

\section{A questionnaire on students' motivation of college English learning}

The following questions aim to survey your motivation in college English study, choose what you think is the proper answer.

Major:

Class:

Grade:

\section{Section Two: A questionnaire on students' motivation of college English learning}

1. I learn English because I want to know English-speaking people and communicate with them.
A. strongly agree
B. agree
C. neutral
D. disagree
E. strongly disagree

2. If my friends or classmates learn English well, I will also study harder.
A. strongly agree
B. agree
C. neutral
D. disagree
E. strongly disagree

3. I study English hard in order to pass some tests, CET-4 for instance.
A. strongly agree
B. agree
C. neutral
D. disagree
E. strongly disagree

4. If I get high marks and material rewards, I will work harder.
A. strongly agree
B. agree
C. neutral
D. disagree
E. strongly disagree

5. I think learning English is very important because it can help me find a good job in the future.
A. strongly agree
B. agree
C. neutral
D. disagree
E. strongly disagree

6. I like learning English because I am very interested in language learning.
A. strongly agree
B. agree
C. neutral
D. disagree
E. strongly disagree

7. I study English because I am interested in foreign literature, culture, songs or movies.
A. strongly agree
B. agree
C. neutral
D. disagree
E. strongly disagree

8. If I have made English learning plans and goals, I will study English harder.

$\begin{array}{lllll}\text { A. strongly agree } & \text { B. agree } & \text { C. neutral } & \text { D. disagree } & \text { E. strongly disagree }\end{array}$

9. I like English because my English teacher is very good.

$\begin{array}{lllll}\text { A. strongly agree } & \text { B. agree } & \text { C. neutral } & \text { D. disagree } & \text { E. strongly disagree }\end{array}$

10. I learn English in order to live up to my parents' expectations.
A. strongly agree
B. agree
C. neutral
D. disagree
E. strongly disagree

11. I work hard at English because I want to learn all my subjects well.
A. strongly agree
B. agree
C. neutral
D. disagree
E. strongly disagree

12. If I am often praised for my good performance or progress, I will study English harder.
A. strongly agree
B. agree
C. neutral
D. disagree
E. strongly disagree

\section{Copyrights}

Copyright for this article is retained by the author(s), with first publication rights granted to the journal.

This is an open-access article distributed under the terms and conditions of the Creative Commons Attribution license (http://creativecommons.org/licenses/by/4.0/). 